Article

\title{
Investigation of the Localized Corrosion and Passive Behavior of Type 304 Stainless Steels with $0.2-1.8$ wt \% B
}

\author{
Heon-Young Ha ${ }^{1, *(\mathbb{D})}$, Jae Hoon Jang ${ }^{1}$, Tae-Ho Lee ${ }^{1}$, Chihyoung Won ${ }^{1,2}$, Chang-Hoon Lee ${ }^{1}$, \\ Joonoh Moon ${ }^{1}$ and Chang-Geun Lee ${ }^{1,2}$ \\ 1 Ferrous Alloy Department, Korea Institute of Materials Science, Changwon 51508, Korea; \\ jhjang@kims.re.kr (J.H.J.); 1th@kims.re.kr (T.-H.L.); kta2017@kims.re.kr (C.W.); lee1626@kims.re.kr (C.-H.L.); \\ mjo99@kims.re.kr (J.M.); lcg0827@kims.re.kr (C.-G.L.) \\ 2 Department of Metallurgical Engineering, Pusan National University, Busan 46241, Korea \\ * Correspondence: hyha2007@kims.re.kr; Tel.: +82-55-280-3422; Fax: +82-55-280-3599
}

Received: 5 May 2018; Accepted: 22 May 2018; Published: 25 October 2018

\begin{abstract}
The pitting corrosion resistance and passive behavior of type 304 borated stainless steels $\left(\mathrm{Fe}_{\text {balance }}-18 \mathrm{Cr}-12 \mathrm{Ni}-1.5 \mathrm{Mn}-(0.19,0.78\right.$, and $\left.1.76 \mathrm{wt} \%) \mathrm{B}\right)$ manufactured through conventional ingot metallurgy were investigated. The alloys were composed of an austenitic matrix and $\mathrm{Cr}_{2} \mathrm{~B}$ phase, and the volume fraction of $\mathrm{Cr}_{2} \mathrm{~B}$ increased from 1.68 to $22.66 \mathrm{vol} \%$ as the $\mathrm{B}$ content increased from 0.19 to $1.76 \mathrm{wt} \%$. Potentiodynamic polarization tests measured in aqueous $\mathrm{NaCl}$ solutions revealed that the pitting corrosion resistance was reduced as the $\mathrm{B}$ content increased and the pits were initiated at the matrix adjacent to the $\mathrm{Cr}_{2} \mathrm{~B}$ phase. It was found that the reduced resistance to pitting corrosion by $\mathrm{B}$ addition was due to the formation of more defective and thinner passive film and increased pit initiation sites in the matrix.
\end{abstract}

Keywords: borated stainless steels; pitting corrosion; passive film

\section{Introduction}

Boron (B)-containing austenitic stainless steels known as borated stainless steels (BSSs) have been widely used in the nuclear industry primarily due to their excellent thermal neutron attenuation capability. The BSSs are used in storage racks and transportation casks for the storage of spent nuclear fuel from power reactors [1-11]. Because the neutron absorption ability directly relies on the B content in the materials $[3,6,8,10]$, the BSS should contain as much B as possible to be safely used as wet storage rack materials for spent nuclear fuel. In addition, desirable strength, formability, and corrosion resistance in a wet storage environment are also required. Eight types of BSSs based on AISI S30400 stainless steel, which meet the requirements of the mechanical properties, are specified in ASTM A 887-89 (ASTM International, West Conshohocken, PA, USA, 2004a) [12] from 304B with $0.20-0.29$ wt \% B to $304 B 7$ with $1.75-2.25$ wt \% B [2,3,7-11].

A small addition of $\mathrm{B}$ of less than approximately $50 \mathrm{ppm}$ to $\mathrm{FeCrNi}$-based austenitic stainless steels is recognized to be beneficial to the creep resistance, hot workability, and intergranular corrosion resistance [13-18]. However, the solubility of B in the austenitic stainless steels is very limited-as low as approximately $100-150$ ppm depending on the matrix composition $[9,13,19]$; thus, the addition of an excessive amount of $B$ inevitably forms $\mathrm{M}_{2} \mathrm{~B}$ (M stands for metal; $\mathrm{Cr}$ and/or Fe) type phase, which is known to degrade the mechanical and corrosion properties $[4-8,13,20]$. The corrosion damage of the stainless steel racks can accelerate the fracture of the structure; thus, the corrosion behavior of BSSs has been investigated and well documented. Loria et al. [13] reported the general corrosion behavior and intergranular corrosion susceptibility of type 304 stainless steel with $0.5 \mathrm{wt} \% \mathrm{~B}$ and without B in 
sulfuric acid solution. He et al. [8] investigated the general and localized corrosion behavior of BSSs (UNS S30464 and UNS S30465) in simulated groundwater at 60-90 ${ }^{\circ} \mathrm{C}$. Lister et al. [7] also examined the general and pitting corrosion resistance of UNS S30464-S30466 alloys (made through powder metallurgy) and type 316 stainless steel with $1 \mathrm{wt} \% \mathrm{~B}$ (made through ingot metallurgy) in aqueous solutions containing $\mathrm{Cl}^{-}$and $\mathrm{NO}_{3}{ }^{-}$. In addition, Moreno et al. [6] focused on the pitting corrosion resistance of UNS S30466 alloy in aqueous solutions with $\mathrm{NaCl}$ and $\mathrm{NaCl}+\mathrm{Na}_{2} \mathrm{~S}$. Upadhyay et al. [20] investigated the localized corrosion resistance of type 304 stainless steels with $(1.2 \mathrm{wt} \%)$ and without $B$ through electrochemical noise analyses and polarization tests. A consensus was found that lower corrosion resistance was obtained in the alloys with higher B content.

Although several researchers have investigated the various types of corrosion of BSSs, little work has been done on the passive behavior of BSSs. In general, the BSSs applied for wet spent fuel storage racks are installed in an on-site spent fuel storage pool, and they are exposed to a relatively mild corrosive environment with low $\mathrm{Cl}^{-}$concentration and near-neutral $\mathrm{pH}$. Under this condition, the overall corrosion resistance of the BSS rack primarily depends on the protectiveness of the passive film; thus, it is necessary to investigate the passive behavior of BSSs. Therefore, the present paper aims to investigate the passive behavior and the resistance to passivity breakdown of type 304 stainless steels ( $\mathrm{Fe}_{\text {balance }} 18 \mathrm{Cr} 12 \mathrm{Ni1} .5 \mathrm{Mn}$-based alloys, in wt \%) containing 0.19-1.76 wt \% B, which were manufactured through conventional ingot metallurgy.

\section{Materials and Methods}

\subsection{Materials}

The investigated alloys were $\mathrm{Fe}_{\text {balance }}$ 18Cr12Ni1.5Mn-based alloys (type 304 stainless steels) containing $0.19-1.76 \mathrm{wt} \% \mathrm{~B}$. The detailed chemical compositions of the alloys are given in Table 1 . The alloys were fabricated through conventional ingot metallurgy. The ingots (50 kg) were reheated at $1150{ }^{\circ} \mathrm{C}$ for $1 \mathrm{~h}$ and then hot-rolled into plates with a thickness of $40 \mathrm{~mm}$. The hot-rolled plates were solutionized at $1050^{\circ} \mathrm{C}$ for $1 \mathrm{~h}$ followed by water quenching. The temperatures for reheating and solutionization were determined based on thermodynamic calculations, which were conducted using ThermoCalc software with the TCFE 7.0 database [21]. Based on the compositions in Table 1, the equilibrium between liquid, $\mathrm{FCC}, \mathrm{BCC}, \mathrm{Cr}_{2} \mathrm{~B}$, and $\mathrm{Cr}_{23} \mathrm{C}_{6}$ phases was estimated.

Table 1. Chemical compositions (in wt \%) of the investigated alloys.

\begin{tabular}{ccccccccc}
\hline Alloy & Fe & Cr & Ni & Mn & Al & C & Si & B \\
\hline B019 & & 17.7 & 11.9 & 1.35 & 0.024 & 0.056 & 0.25 & 0.19 \\
B078 & Balance & 18.4 & 12.3 & 1.55 & 0.035 & 0.066 & 0.26 & 0.78 \\
B176 & & 18.3 & 12.4 & 1.57 & 0.039 & 0.073 & 0.28 & 1.76 \\
\hline
\end{tabular}

For microstructure observation, the alloy specimens $(15 \mathrm{~mm} \times 10 \mathrm{~mm} \times 3 \mathrm{~mm})$ were polished using a diamond suspension with a particle size of $1 \mu \mathrm{m}$ and then etched using a mixed solution of $30 \mathrm{~mL} \mathrm{HCl}+20 \mathrm{~mL} \mathrm{HNO}_{3}+50 \mathrm{~mL}$ ethanol. The microstructures of the specimens were observed using an optical microscope (Epiphot, Nikon, Japan) and a scanning electron microscope (SEM, JSM-7100F, JEOL, Tokyo, Japan). In addition, the chemical composition of the second phase was investigated using electron probe microanalysis with wavelength dispersive spectrometry (EPMA-WDS, JXA-8530F, JEOL). Based on the micrographs, fractions and sizes of the second phases were measured using Image-Pro Plus 7.1 software (Media Cybernetics, Silver Spring, MD, USA). For the analyses of the second phase formed after solution treatment, a transmission electron microscope (TEM, JEM-2100F, JEOL, Japan) operating at $200 \mathrm{kV}$ was used. In order to identify the second phase directly, a dual beam system (NOVA 200, FEI Company, Hillsboro, OR, USA) composed of both focused ion beam (FIB) and high-resolution SEM columns was used. Cross-section milling was performed with $30 \mathrm{kV}$ Ga ions. $\mathrm{Pt}$ was deposited on the interface between the Omni-probe and sample, and the final cuts were made 
by FIB. The standard lift-out technique was used where the specimen was removed from the trench using an Omni-probe and placed on a $\mathrm{Cu}$ grid for TEM observation.

\subsection{Pitting Corrosion Resistance}

The resistance to pitting corrosion of the alloys was evaluated through polarization and immersion tests in aqueous solutions containing $\mathrm{Cl}^{-}$. The polarization tests were conducted in $10 \mathrm{ppm}$ and $58 \mathrm{ppm}$ $\mathrm{NaCl}$ solutions at $20 \pm 1{ }^{\circ} \mathrm{C}$, and the potential sweep rate was $2 \mathrm{mV} \mathrm{s}^{-1}$. After the test, the pit initiation sites were observed using SEM and a surface profiler (Wyko NT8000, Veeco, Plainview, NY, USA [22]). The immersion tests were conducted in $3.5 \mathrm{wt} \%(=0.6 \mathrm{M}) \mathrm{NaCl}$ solution for 35 days at $20 \pm 1{ }^{\circ} \mathrm{C}$. For the immersion tests, the specimens $(40 \mathrm{~mm} \times 10 \mathrm{~mm} \times 3 \mathrm{~mm})$ were polished using a $1 \mu \mathrm{m}$ sized diamond suspension.

\subsection{Passive Film Properties}

Passive behavior and passive film properties were investigated. For these investigations, a borate-phosphate-citric buffer solution with $\mathrm{pH} 8.5(0.2 \mathrm{M}$ boric acid $+0.05 \mathrm{M}$ citric acid $+0.1 \mathrm{M}$ tertiary sodium phosphate) was used, which is proven to form a stable and thick passive film on Fe-based alloys [23]. The polarization behavior of the alloy was examined through potentiodynamic polarization tests in the buffer solution at $20 \pm 1{ }^{\circ} \mathrm{C}$ at a potential sweep rate of $2 \mathrm{mV} \mathrm{s}^{-1}$ in order to measure the potential range for the stable passive state and passive current density ( $\left.\mathrm{i}_{\text {passive }}\right)$.

Then the chemical and electronic properties of the passive films were investigated. The chemical composition of the passive film was examined through X-ray photoelectron spectroscopy (XPS, PHI 5000 VersaProbe, ULVAC-PHI, Kanagawa, Japan) using an Al K $\alpha$ anode X-ray source $(150 \mathrm{~W}, 15 \mathrm{kV}$, $\mathrm{h} v=1486.6 \mathrm{eV})$. For the XPS analysis, the passive films were formed on the BSSs in the buffer solution ( $\mathrm{pH}$ 8.5) by applying constant anodic potential of $0 \mathrm{~V}_{\mathrm{SCE}}$ for $3 \mathrm{~h}$.

Regarding the electronic properties of the passive film, the point defect density of the space charge layer of the passive film was investigated through Mott-Schottky analysis. For this, the passive film was potentiostatically grown by applying constant anodic potential of $0.6 \mathrm{~V}_{\mathrm{SCE}}$ for $1 \mathrm{~h}$ in the borate-phosphate-citric buffer solution ( $\mathrm{pH} 8.5)$, and then the capacitance of the passivated layer was measured at a frequency of $1000 \mathrm{~Hz}$ with an imposing sinusoidal voltage perturbation of $\pm 0.01 \mathrm{~V}$ (peak-to-peak) during the negative potential sweep from 0.6 to $-0.7 \mathrm{~V}_{\mathrm{SCE}}$ with a potential sweep rate of $0.01 \mathrm{~V} \mathrm{step}^{-1}$.

All of the polarization tests and capacitance measurements (Mott-Schottky analysis) were conducted in a standard three-electrode setup with the metal specimen being a working electrode, a Pt plate $(50 \mathrm{~mm} \times 120 \mathrm{~mm} \times 0.1 \mathrm{~mm})$ as a counter electrode, and a saturated calomel reference electrode (SCE) as a reference electrode; the electrochemical tests were controlled by a potentiostat (Reference 600, GAMRY Instruments, Philadelphia, PA, USA). For the working electrode, the specimens $(10 \mathrm{~mm} \times 10 \mathrm{~mm} \times 3 \mathrm{~mm})$ were mounted in cold epoxy resin and then mechanically ground using SiC emery paper up to 2000 grit. The polarization test was performed on an exposed area of $0.2 \mathrm{~cm}^{2}$, which was controlled using electroplating tape. The polarization tests were performed on each specimen 3-5 times, and the capacitance of the passive layer was repetitively measured on each specimen three times in order to confirm reproducibility.

\section{Results and Discussion}

\subsection{Microstructure}

Figure 1 shows the equilibrium phase fractions as a function of temperature. In the case of B019 alloy, the pure liquid state is stable above $1424^{\circ} \mathrm{C}$, and the fraction of austenite phase increases as the temperature decreases. Therefore, during the cooling process from the liquid, austenite phase is firstly formed and then $\mathrm{Cr}$ and $\mathrm{B}$ become enriched in the liquid phase. When the remaining liquid reaches a critical temperature, a eutectic reaction occurs in which austenite and $\mathrm{Cr}_{2} \mathrm{~B}$ are simultaneously 
produced in the liquid. These eutectic reactions similarly occur in B078 and B176 alloys. The melting points of the B019, B078, and B176 alloys are 1270,1273 , and $1274{ }^{\circ} \mathrm{C}$, respectively. The differences in the melting points are induced by other alloying elements distributed in the austenite phase. In the case of B176 containing $1.76 \mathrm{wt} \% \mathrm{~B}$, the eutectic reaction mainly occurred without producing a pro-eutectic phase. The results of the reactions were confirmed in the microstructure observations in Figure 2.

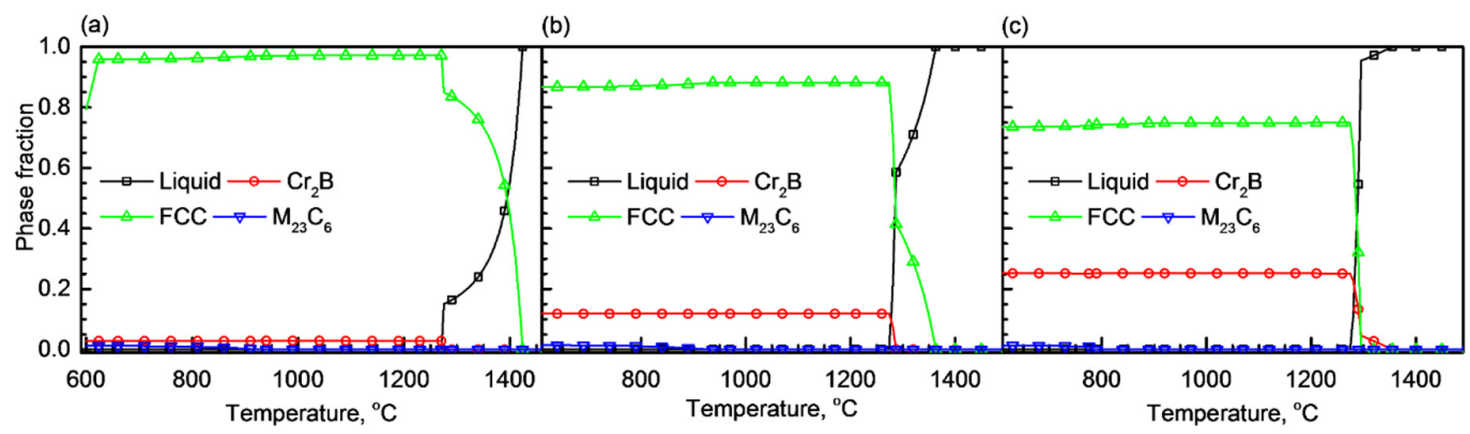

Figure 1. Equilibrium phase diagrams of (a) B019, (b) B078, and (c) B176 alloys calculated using Thermo-Calc software.

Figure 2a-1-c-2 is SEM images of B019, B078, and B176 alloys showing the distribution of the second phase in the matrix. The second phases were irregular in shape as well as size (ranging over 2-30 $\mu \mathrm{m}$ ) and were not homogeneously distributed over the matrix. The microstructure of the B019 alloy (Figure 2a-1-a-4) shows the mixture of the second phases and austenite formed by the eutectic reaction around the austenite that first formed during cooling. On the other hand, in the case of the B176 alloy (Figure 2c-1-c-4), the second phase was distributed rather homogeneously in the austenite matrix. The measured fractions of the second phases in the B019, B078, and B176 alloys were $1.68 \pm 0.49,9.73 \pm 0.28$, and $22.66 \pm 0.8 \mathrm{vol} \%$, respectively, which are similar to the predicted values from the thermodynamic calculation.

In the B019 alloy (Figure 2a-2), second phases with needle-like shapes were observed, and as the $\mathrm{B}$ content increased to 0.78 and $1.76 \mathrm{wt} \%$ (Figure $2 \mathrm{~b}-2$ and c-2, respectively), both the volume fraction and number of the second phases increased, and the platelike-shaped second phases were frequently found in the B176 alloy.

The equilibrium phase diagrams in Figure 1 suggest that the relatively dark phase shown in the SEM images (Figure 2) is $\mathrm{Cr}_{2} \mathrm{~B}$ and that the matrix is austenite, which was confirmed by the composition analysis through the EPMA (Figure 3). Figure 3a-c shows back-scattered electron (BSE) images and the elemental maps (Cr, B, Fe, and Ni) of the B019, B078, and B176 alloys. In the BSE images (Figure 3a-BSE-c-BSE), the second phase appears in dark gray in comparison with the matrix (light gray), which indicates that the second phase contains heavier elements than the matrix. Figure $3 \mathrm{a}-\mathrm{Cr}-\mathrm{c}-\mathrm{Fe}$ clearly shows that $\mathrm{Cr}$ and $\mathrm{B}$ are enriched with the second phase where Fe is slightly depleted. Ni is rarely detected in the second phase as shown in Figure 3a-Ni-c-Ni.

Shown in Figure 4 are SEM micrographs of FIB sampling, bright field (BF) TEM images, and selected area diffraction patterns (SADP) of the second phase as well as the matrix taken from the B078 specimen. Based on the analyses of SADP, the second phase was confirmed to be $\mathrm{Cr}_{2} \mathrm{~B}$ with orthorhombic structure (space group: $\mathrm{F} d d d$ ) and the lattice parameters of $\mathrm{Cr}_{2} \mathrm{~B}$ are $a=0.4275 \mathrm{~nm}$, $b=0.7452 \mathrm{~nm}$, and $c=1.4795 \mathrm{~nm}$.

Because the second phase is the $(\mathrm{Cr}, \mathrm{B})$-enriched phase, the concentrations of $\mathrm{Cr}$ and $\mathrm{B}$ in solid solution state in the matrix consequently decrease as the volume fraction of $\mathrm{Cr}_{2} \mathrm{~B}$ increases. Most of the alloyed $\mathrm{B}$ was consumed by forming $\mathrm{Cr}_{2} \mathrm{~B}$; thus, the concentrations of $\mathrm{B}$ in solid solution state of the austenite matrices of the three BSSs were calculated to be less than approximately $2.0 \times 10^{-5} \mathrm{wt} \%$. Accordingly, the $\mathrm{Cr}$ content in the matrix decreased as the alloyed B content increased. The $\mathrm{Cr}$ contents 
of the austenitic matrices of B019, B078, and B176 alloys at solution treatment temperature were calculated to be $16.67,13.65$, and 9.21 wt \%, respectively. On the other hand, Ni and Mn, which did not participate in forming $\mathrm{Cr}_{2} \mathrm{~B}$, were anticipated to be enriched in the austenitic matrix. Indeed, the calculated Ni contents of the austenitic matrices increased from $12.34 \mathrm{wt} \%$ for the B019 alloy to $14.85 \mathrm{wt} \%$ for the B176 alloy. Those of Mn also increased from $1.38 \mathrm{wt} \%$ for the B019 alloy to $1.68 \mathrm{wt} \%$ for the B176 alloy.

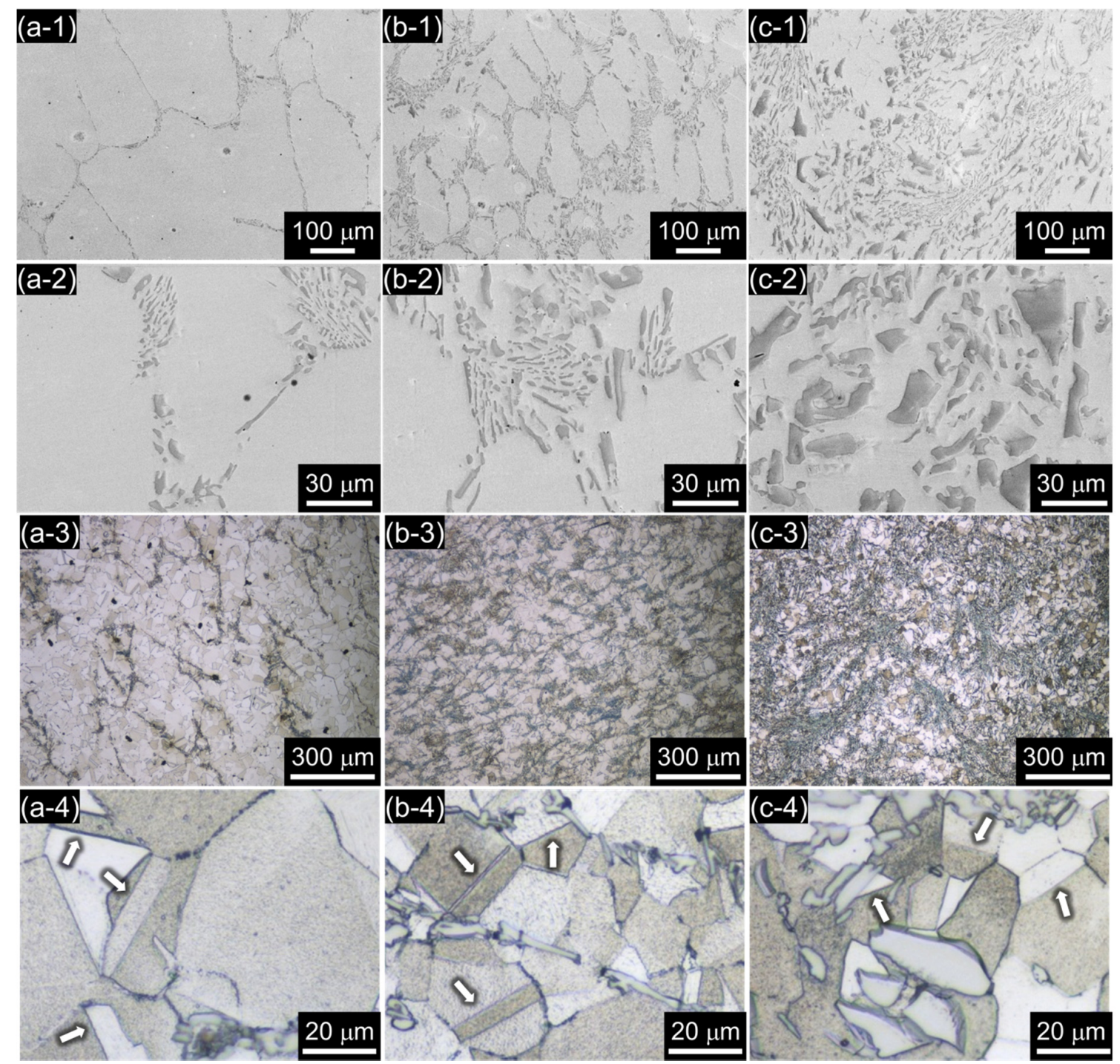

Figure 2. Microstructures of (a) B019, (b) B078, and (c) B176 alloys. SEM images of the alloys taken at $(\mathbf{a}-\mathbf{1}, \mathbf{b}-\mathbf{1}, \mathbf{c}-\mathbf{1})$ low and $(\mathbf{a}-\mathbf{2}, \mathbf{b}-\mathbf{2}, \mathbf{c}-2)$ high magnification, and optical micrographs of the alloys taken at $(a-3, b-3, c-3)$ low and $(a-4, b-4, c-4)$ high magnification.

Figure 2a-3-c-4 is optical micrographs of the three alloys, which were polished and etched in acidic solution to identify the grain boundary. In the three alloys, the annealing twins (marked by arrows in Figure 2a-4-c-4) were frequently observed in the polycrystallized matrix, confirming that the matrix was recrystallized austenite. It is noted that the average grain diameter decreases as the $B$ content increases, because the eutectic $\mathrm{Cr}_{2} \mathrm{~B}$ effectively blocks grain boundary migration during the heat treatment. 


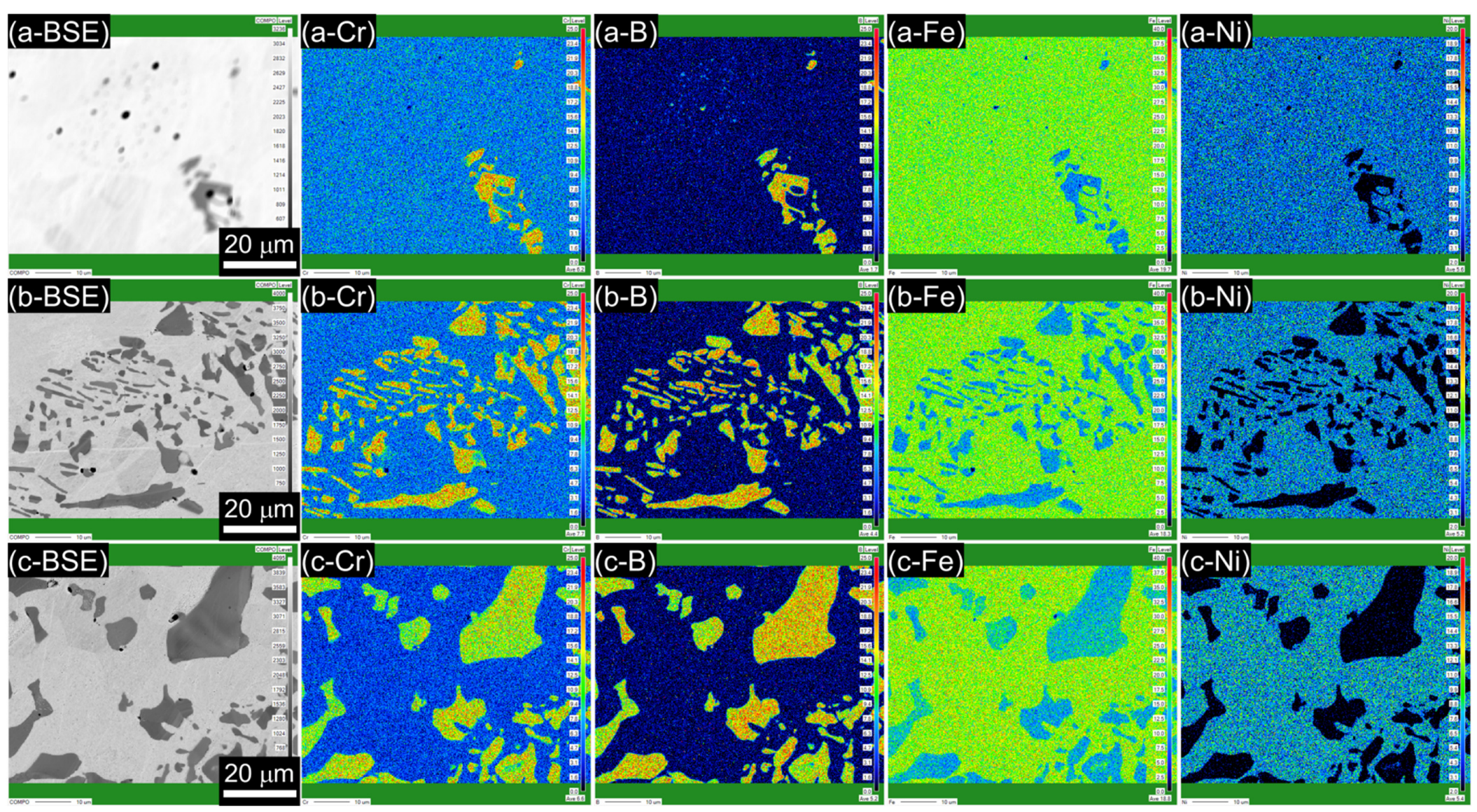

Figure 3. Elemental X-ray mapping of Cr, B, Fe, and Ni along with the corresponding back-scattered electron (BSE) images of the (a) B019, (b) B078, and (c) B176 alloys. 


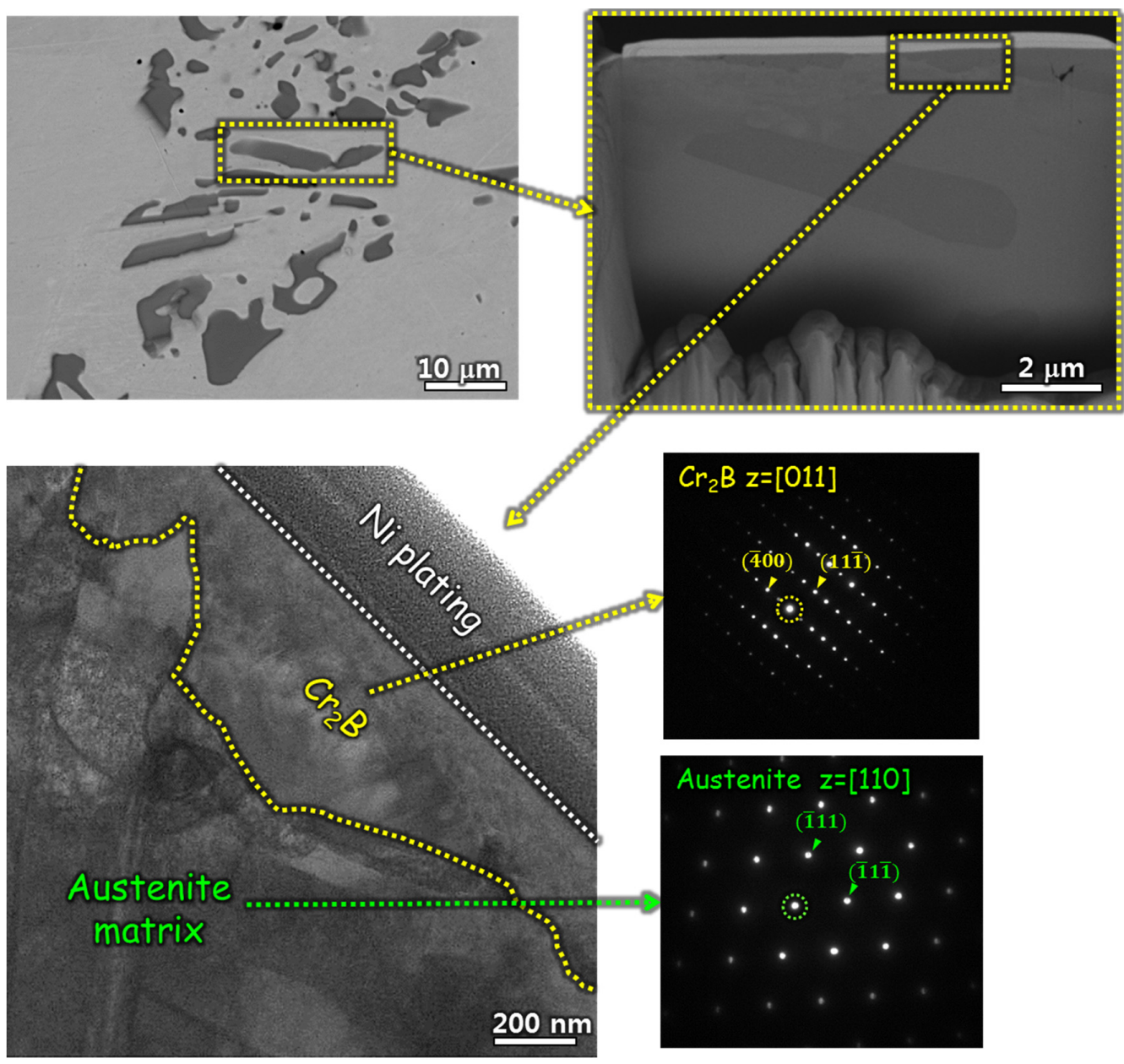

Figure 4. Procedure of focused ion beam (FIB) sampling, bright field (BF) imaging, and corresponding selected area diffraction (SAD) patterns of $\mathrm{Cr}_{2} \mathrm{~B}$ and the austenite matrix taken from the B078 alloy. 


\subsection{Pitting Corrosion Resistance}

Figure 5a,b exhibits the potentiodynamic polarization curves of the B019, B078, and B176 alloys measured in $10 \mathrm{ppm}$ and $58 \mathrm{ppm} \mathrm{NaCl}$ solutions, respectively. As shown in Figure $5 \mathrm{a}, \mathrm{b}$, the three BSSs passivate in the dilute $\mathrm{NaCl}$ solutions under the open circuit condition and do not exhibit active-passive transition. In the $10 \mathrm{ppm} \mathrm{NaCl}$ solution (Figure 5a), the $\mathrm{E}_{\text {corr values of the three alloys }}$ were $-0.274 \mathrm{~V}_{\mathrm{SCE}}$, and those were slightly shifted to the lower potential of $-0.353 \mathrm{~V}_{\mathrm{SCE}}$ in the $\mathrm{NaCl}$ solution with increased $\mathrm{NaCl}$ concentration (Figure $5 b$ ). For the three alloys, stable passivity appeared only in the limited potential range from the $\mathrm{E}_{\mathrm{corr}}$ to the pitting potential $\left(\mathrm{E}_{\mathrm{pit}}\right)$. The average $\mathrm{E}_{\text {pit }}$ was calculated from repetitive polarization tests and is plotted in Figure $5 \mathrm{c}$ as a function of the B content. Higher $\mathrm{E}_{\text {pit }}$ was obtained in more dilute $\mathrm{NaCl}$ solution, as expected, and it was clear that the $\mathrm{E}_{\mathrm{pit}}$ was linearly lowered with an increase in the B content in the alloys. Therefore, it could be concluded that the resistance to pitting corrosion of the BSSs was degraded as the B content increased.
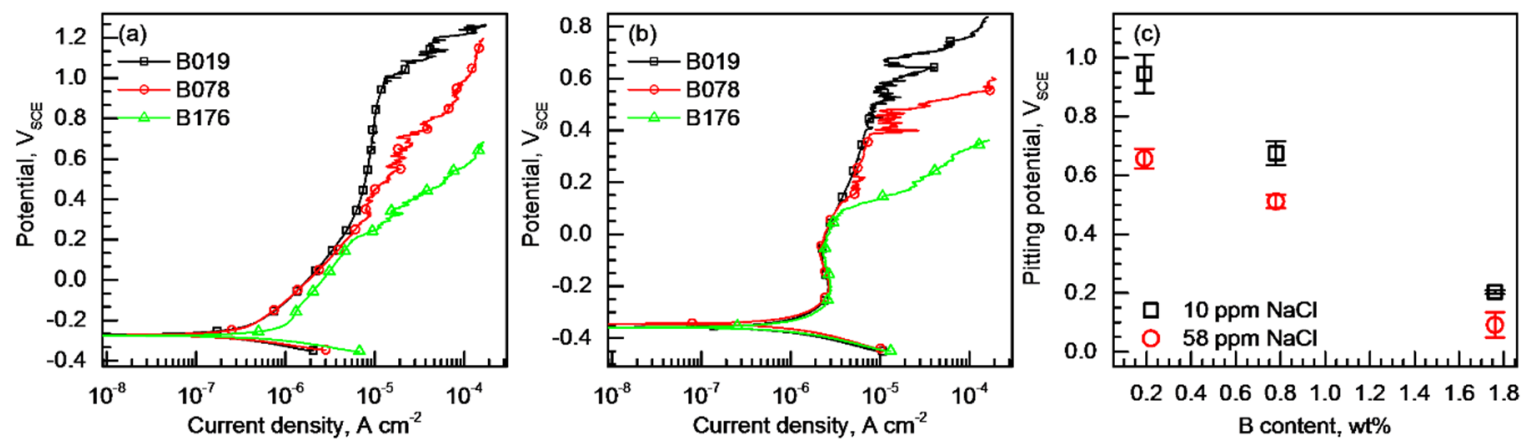

Figure 5. Potentiodynamic polarization curves of the alloys measured in (a) $10 \mathrm{ppm}$ and (b) $58 \mathrm{ppm}$ $\mathrm{NaCl}$ solutions at $20 \pm 1{ }^{\circ} \mathrm{C}$ at a potential sweep rate of $2 \mathrm{mV} \mathrm{s}^{-1}$; (c) Variation of the average pitting potentials of the alloys as a function of the B content.

Figure 6 shows the corroded surfaces of the three alloy specimens after immersion in a $3.5 \mathrm{wt} \%$ $\mathrm{NaCl}$ solution for 35 days. Figure 6 confirms the decrease in the resistance to pitting corrosion along with the increase in the $\mathrm{B}$ content in the alloys. The photos demonstrate that pitting corrosion is the primary corrosion type in this $\mathrm{Cl}^{-}$-containing environment, and the number of pits and damaged area increase as the B content increases in the alloys.
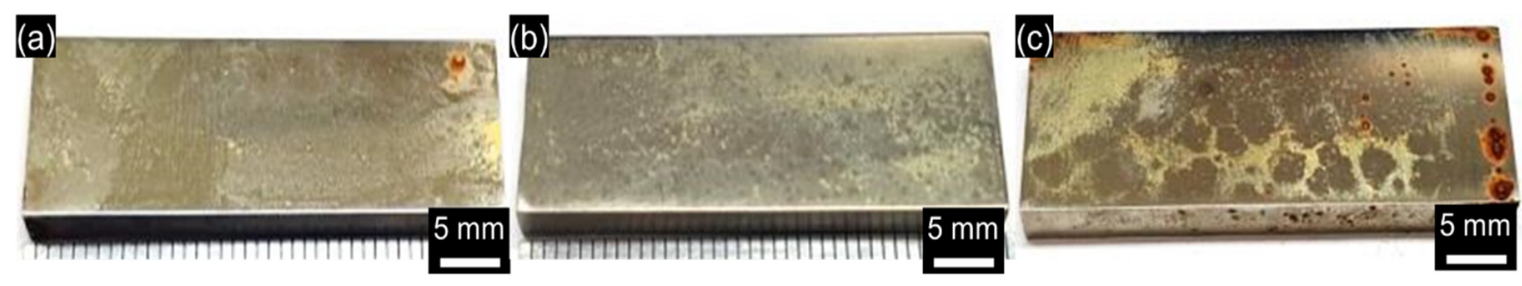

Figure 6. Corrosion morphologies of (a) B019, (b) B078, and (c) B176 alloys after immersion tests in a $0.6 \mathrm{M} \mathrm{NaCl}$ solution at $20 \pm 1{ }^{\circ} \mathrm{C}$ for 35 days.

Figure 7a-c shows SEM images of the pit initiation sites observed in B019, B078, and B176 specimens, respectively. In all of the alloys, pits are initiated at the matrix adjacent to the $\mathrm{Cr}_{2} \mathrm{~B}$ and propagated into the matrix. Figure $7 \mathrm{~d}-\mathrm{f}$ exhibits 3-dimensional surface topographies of the pitted BSS specimens measured through a surface profiler. In the topographies, the higher phase (red color) than the matrix (green and blue color) is $\mathrm{Cr}_{2} \mathrm{~B}$ due to its higher hardness than that of the matrix [24]. Figure $7 \mathrm{~d}-\mathrm{f}$ also clearly demonstrate that the pitting corrosion occurs at the boundary between the $\mathrm{Cr}_{2} \mathrm{~B}$ and the matrix, which corrodes while the $\mathrm{Cr}_{2} \mathrm{~B}$ remains intact $[7,11,20]$. 


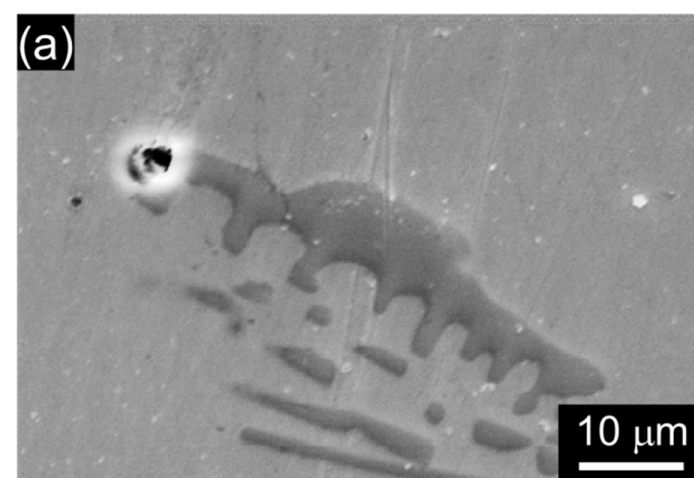

(d)

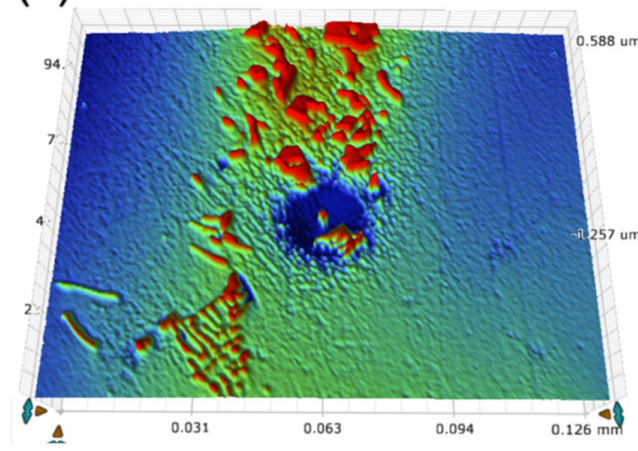

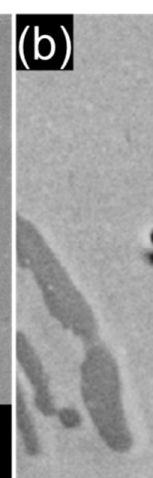

(e)

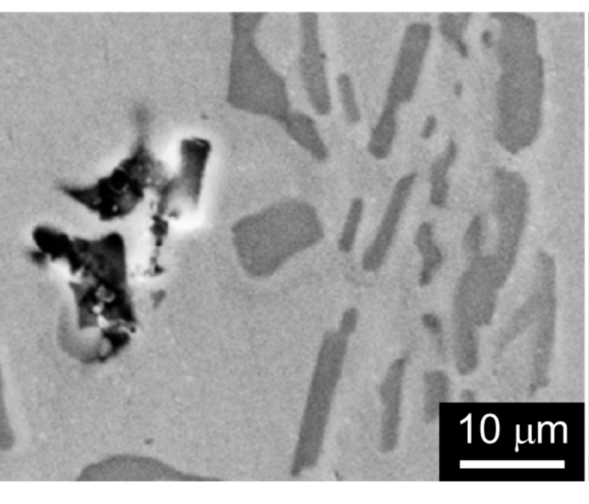

(f)

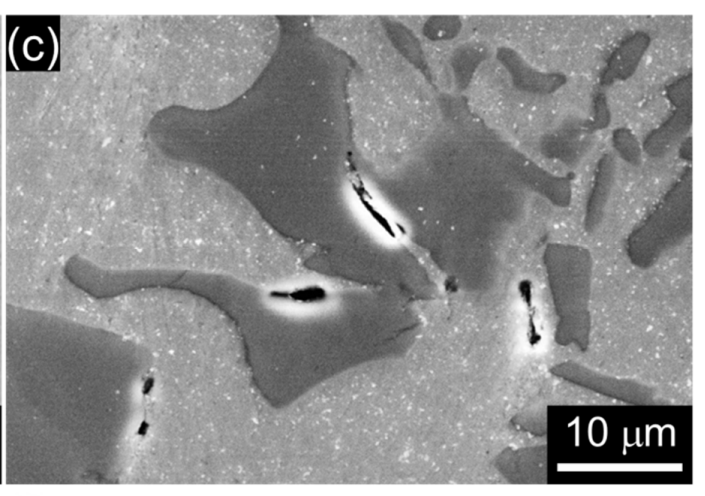

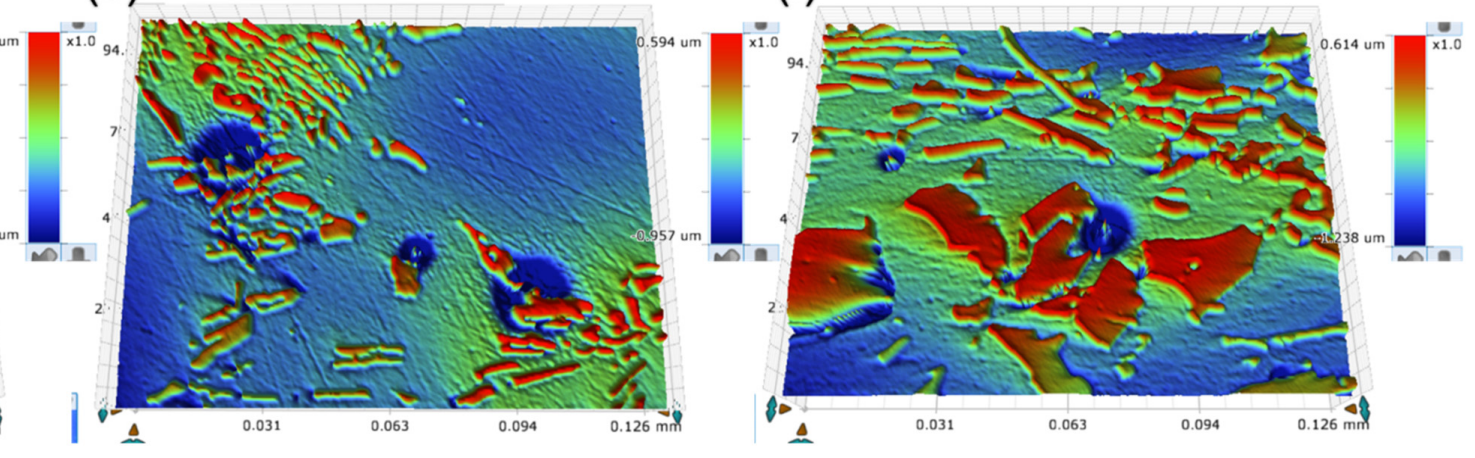

Figure 7. SEM images of the pit initiation sites of (a) B019, (b) B078, and (c) B176 alloys. Three-dimensional surface topographies of the pit initiation sites of (d) B019, (e) B078, and (f) B176 alloys. 


\subsection{Passive Film Analysis}

The passive behavior of the BSSs was evaluated. Figure 8a shows potentiodynamic polarization curves of the alloys measured in the borate-phosphate-citric buffer solution at $\mathrm{pH}$ 8.5. All of the alloys exhibit passive behavior in this solution without active-passive transition, and the $\mathrm{E}_{\text {corr }}$ values of the alloys are approximately $-0.66 \mathrm{~V}_{\mathrm{SCE}}$. In the polarization curves of the BSSs, there are three current peaks at $-0.55,-0.33$, and $0.57 \mathrm{~V}_{\mathrm{SCE}}$, indicated by arrows in Figure $8 \mathrm{a}$. Peak I at $-0.55 \mathrm{~V}_{\mathrm{SCE}}$ is attributed to the oxidation of $\mathrm{Fe}$ to $\mathrm{Fe}^{2+}$, and Peak II at $-0.33 \mathrm{~V}_{\mathrm{SCE}}$ is due to the reoxidation of $\mathrm{Fe}^{2+}$ to $\mathrm{Fe}^{3+}$. Peak III at $0.57 \mathrm{~V}_{\mathrm{SCE}}$ reflects the reoxidation reaction of $\mathrm{Cr}^{3+}$ to $\mathrm{Cr}^{6+}$. In addition, the rapid increase in the current density above approximately $0.65 \mathrm{~V}_{\mathrm{SCE}}$ is due to oxygen evolution (that is, transpassive reaction) [25-28]. The polarization curves exhibit that the potential range for the stable passivity extends from $\mathrm{E}_{\mathrm{Corr}}$ (approximately $-0.66 \mathrm{~V}_{\mathrm{SCE}}$ ) to approximately $0.65 \mathrm{~V}_{\mathrm{SCE}}$. In the passive potential range, the lowest $i_{\text {passive }}$ is observed at approximately $0 \mathrm{~V}_{\mathrm{SCE}}$. The average $i_{\text {passive }}$ values (measured at $0 \mathrm{~V}_{\mathrm{SCE}}$ ) of the alloys were calculated from the repetitively measured polarization curves $3-5$ times and plotted versus the $B$ content (Figure $8 b$ ). The minimum $i_{\text {passive }}$ value increased from 7.32 to $10.05 \mu \mathrm{A} \mathrm{cm}^{-2}$ as the B content increased from 0.19 to $1.76 \mathrm{wt} \%$; thus, it was concluded that the passive film with the highest resistance was formed on the BSS containing the lowest B content. It is worth mentioning the decrease in the grain size of the austenite matrix of the BSSs as shown in Figure 2a-3-c-4. The grain refinement is known to accelerate passivation, resulting in the formation of a thick and dense passive film [29-31]; thus, the $i_{\text {passive }}$ is generally lowered when the grain size of the matrix decreases [32]. In this case, however, the $i_{\text {passive }}$ of the BSSs apparently increased although the grain size of the austenite matrix decreased; thus, it is reasonable to conclude that the change in the grain size is not the dominant factor for determining the magnitude of the $i_{\text {passive }}$.
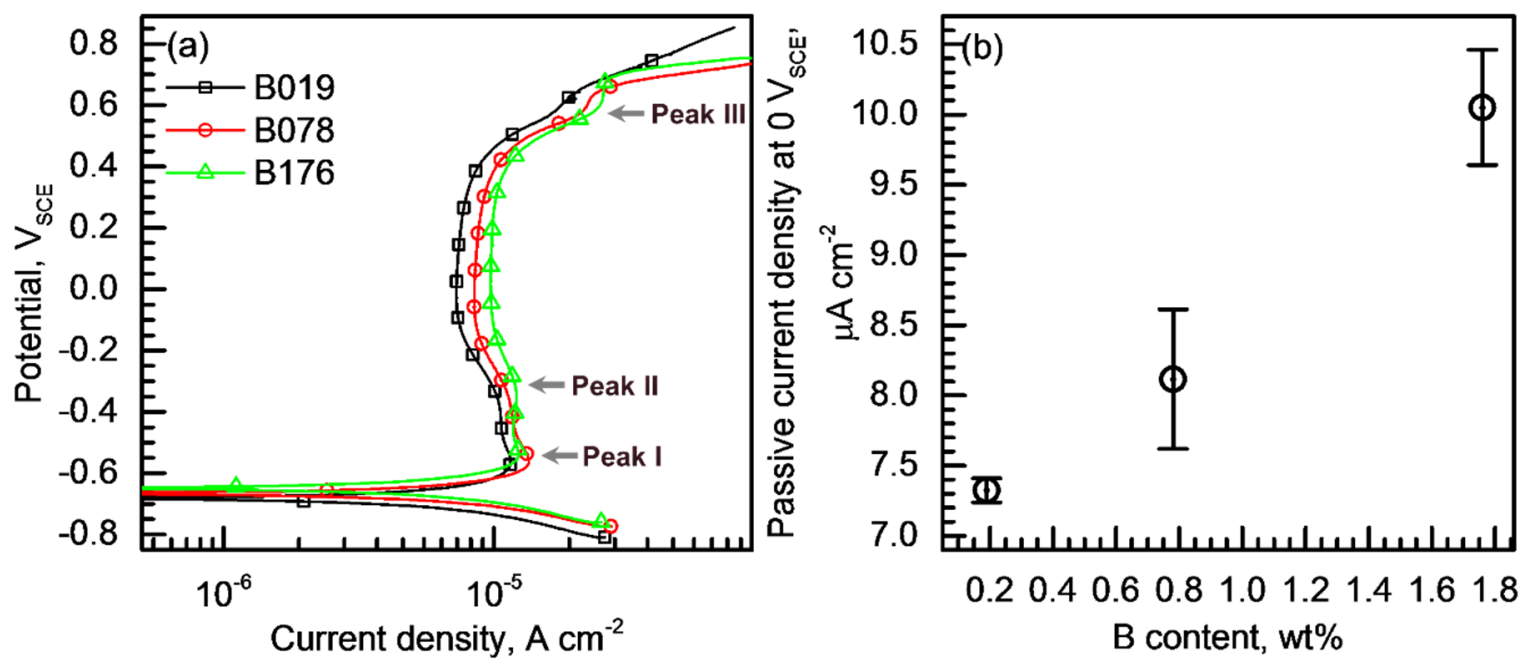

Figure 8. (a) Potentiodynamic polarization curves of the alloys measured in a borate-phosphate-citric buffer solution with $\mathrm{pH} 8.5(0.2 \mathrm{M}$ boric acid $+0.05 \mathrm{M}$ citric acid + 0.1 M tertiary sodium phosphate) at $20 \pm 1{ }^{\circ} \mathrm{C}$ at a potential sweep rate of $2 \mathrm{mV} \mathrm{s}^{-1}$; (b) Variation of the average passive current density values of the alloys as a function of the $\mathrm{B}$ content.

The chemical composition and structure of the passive film were examined using XPS. For this analysis, the passive film was potentiostatically formed in the borate-phosphate-citric buffer solution ( $\mathrm{pH}$ 8.5), and the film formation potential was determined to be $0 \mathrm{~V}_{\mathrm{SCE}}$, at which the lowest $\mathrm{i}_{\text {passive }}$ was observed as presented in Figure 8a. Figure 9a-c shows the concentration depth profiles of the B019, B078, and B176 alloys, respectively. Figure 9 demonstrates that stable passive films with similar structure and chemical composition were formed on the three BSSs. The passive films were primarily composed of $\mathrm{Fe}, \mathrm{Cr}$, and $\mathrm{O}$ with a small amount of $\mathrm{Mn}$ (less than 0.05 atom \%). A notable difference 
among the passive films of the three BSSs was observed in the film thickness. The thickness of the passive film can be estimated from the concentration depth profile of $\mathrm{O}$ (Figure $9 \mathrm{~d}$ ) by taking the depth from the surface at which the $50 \%$ value of the $\mathrm{O}$ amplitude appears $[31,33,34]$. The thickness of the passive film formed on the B176 alloy was calculated to be $1.823 \mathrm{~nm}$, while that on the B019 alloy was $2.469 \mathrm{~nm}$. That is, a thinner passive film was formed on the BSS with higher B content. In addition, the $\mathrm{Cr}$ content was also affected by the B content in the matrix. As shown in Figure 9e, the $\mathrm{Cr}$ contents at the film surface of the B019, B078, and B176 alloys were 6.80, 7.39, and 9.89 atom \%, respectively, and the $\mathrm{Cr}$ content inside the passive film was also slightly higher in the B176 alloy than in the other alloys.
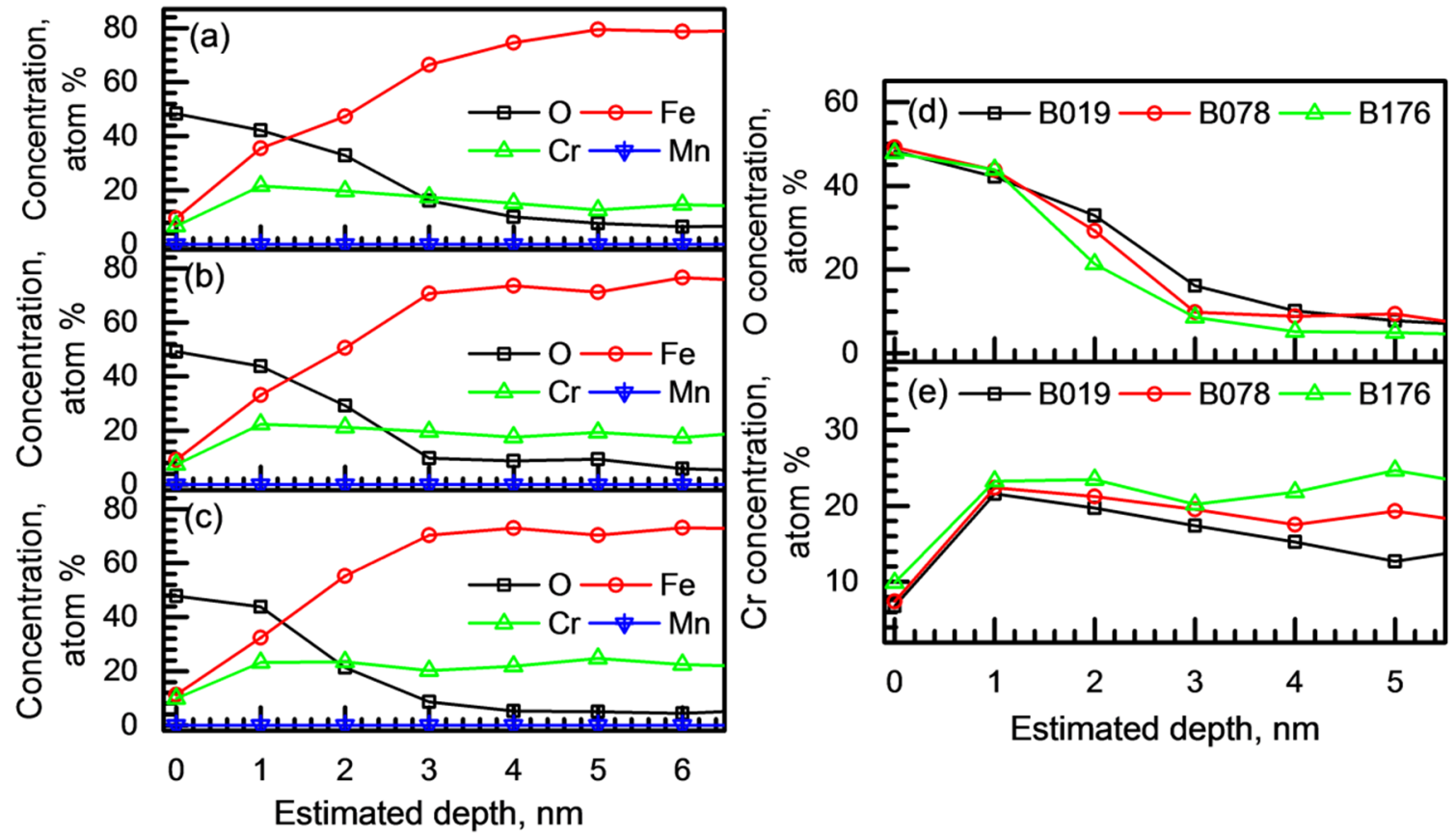

Figure 9. Chemical composition depth profiles of the passive films of (a) B019, (b) B078, and (c) B176 alloys analyzed through XPS; (d) O and (e) Cr concentration profiles of the passive films formed on the alloys. The passive films were formed in a borate-phosphate-citric buffer solution ( $\mathrm{pH} 8.5$ ) by applying constant anodic potential of $0 \mathrm{~V}_{\mathrm{SCE}}$ for $3 \mathrm{~h}$.

Then, the point defect density in the passive film was measured through Mott-Schottky analysis. Generally, the passive film of stainless steel formed in an aqueous solution is known to contain large numbers of point defects such as oxygen vacancies $\left(\mathrm{V}_{\mathrm{O}}{ }^{2+}\right)$, metal vacancies $\left(\mathrm{V}_{\mathrm{M}^{\mathrm{x}}}{ }^{\mathrm{w}}\right)$, and cation interstitials $\left(\mathrm{M}_{\mathrm{i}}{ }^{\mathrm{x}}\right)$; thus, the passive film behaves as an extrinsic semiconductor. The point defect density of the space charge layer in the passive film can be calculated through the capacitance measurement, which is Mott-Schottky analysis. For Mott-Schottky analyses, the specific interfacial capacitance $\left(C_{\text {total }}\right)$ of the passivated surface is obtained using $C_{\text {total }}=1 / \omega \mathrm{Z}^{\prime \prime}$, where $\omega$ is the angular frequency and $Z^{\prime \prime}$ is the imaginary part of the specific impedance. The measured capacitance $\left(C_{\text {total }}\right)$ is a series combination of the double layer capacitance (Helmholtz layer capacitance, $C_{H}$ ) and space charge layer capacitance $\left(C_{S C}\right)$. The $C_{S C}$ of the n-type semiconductor and the relationship between $C_{\text {total }}, C_{H}$, and $C_{S C}$ are given as follows:

$$
\frac{1}{C_{S C}^{2}}=\frac{1}{C_{\text {total }}^{2}}-\frac{1}{C_{H}^{2}}=\left(\frac{2}{\varepsilon \varepsilon_{0} e N_{D}}\right)\left(E_{a p p}-E_{f b}-\frac{k_{B} t}{e}\right)
$$

where $\varepsilon$ is the dielectric constant of the passive film (15.6 for the passive film of stainless steel $[35,36]$ ), $\varepsilon_{0}$ is the vacuum permittivity $\left(8.854 \times 10^{14} \mathrm{~F} \mathrm{~cm}^{-1}\right), e$ is the electron charge, $E_{a p p}$ is the applied potential, 
and $k$ is the Boltzmann constant. Thus, for an n-type semiconductor, a graph of $C_{S C}{ }^{-2}$ versus $E_{a p p}$ should be linear with a positive slope and $C_{S C}{ }^{-2}$ is inversely proportional to donor density $\left(N_{D}\right)$. In the Mott-Schottky relationship, $C_{H}$ is sufficiently higher than $C_{S C}$; therefore, it can be neglected in a series of combinations with the $C_{S C}$. Thus, the measured capacitance $\left(C_{\text {total }}\right)$ can be assumed to be equal to $C_{S C}$.

Mott-Schottky plots of the BSSs are presented in Figure 10a, as measured in the borate-phosphate-citric buffer solution at $\mathrm{pH}$ 8.5. For the Mott-Schottky analysis, the passive film was formed by applying constant anodic potential of $0.6 \mathrm{~V}_{\mathrm{SCE}}$ for $1 \mathrm{~h}$ and capacitance was then measured at a constant frequency of $1 \mathrm{kHz}$ with an imposing sinusoidal voltage perturbation of $\pm 10 \mathrm{mV}$ in a potential range from $0.6 \mathrm{~V}_{\mathrm{SCE}}$ to $-0.7 \mathrm{~V}_{\mathrm{SCE}}$. The XPS analysis (Figure 9) confirmed that the passive films formed on the BSSs were (Fe,Cr)-oxide, which is known to have n-type semiconductivity. In accordance with the Mott-Schottky relation (Equation (1)), the n-type semiconductor passive film exhibits a positive slope $\left(\Delta C_{\text {total }}{ }^{-2} / \Delta V\right)$ in the Mott-Schottky plot, and the dominant and detective point defects in the n-type semiconductor passive film are $V_{O^{2+}}$ (shallow donor) and $\mathrm{Cr}^{6+}$ (deep donor). In order to investigate the densities of both donors, film formation for Mott-Schottky analysis was conducted by applying anodic potential between peak $\mathrm{III}\left(\mathrm{Cr}^{3+} \rightarrow \mathrm{Cr}^{6+}\right.$, shown in Figure 8a) and the transpassive potential where oxygen evolution occurred.
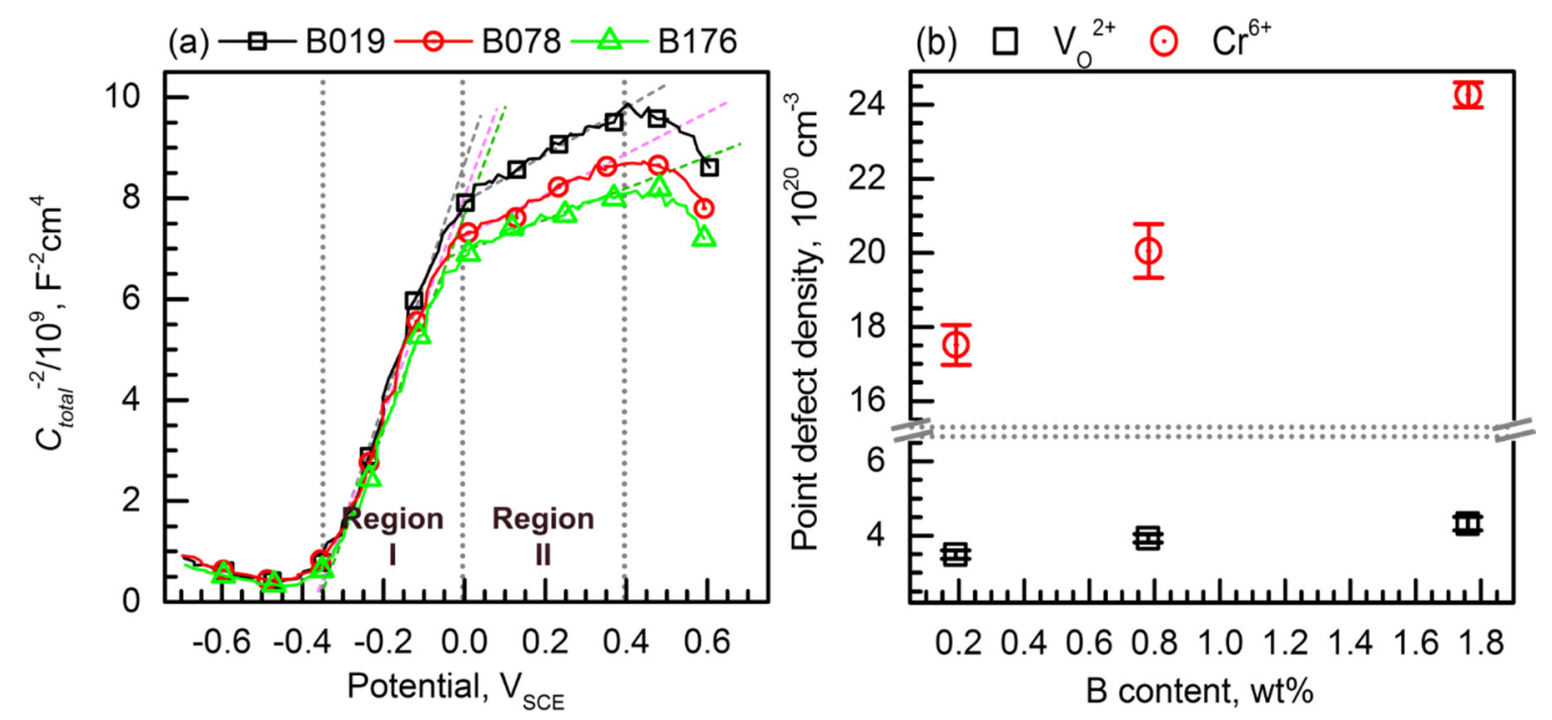

Figure 10. (a) Mott-Schottky plots for the passive films formed on the borated stainless steels (BSSs). The passive films were formed in a borate-phosphate-citric buffer solution ( $\mathrm{pH}$ 8.5) by applying constant anodic potential of $0.6 \mathrm{~V}_{\mathrm{SCE}}$ for $1 \mathrm{~h}$, and the capacitance of the passivated layer was measured at a frequency of $1000 \mathrm{~Hz}$ with an imposing sinusoidal voltage perturbation of $\pm 0.01 \mathrm{~V}$ (peak-to-peak);

(b) Variations of the densities of the point defects $\left(\mathrm{V}_{\mathrm{O}}{ }^{2+}\right.$ and $\left.\mathrm{Cr}^{6+}\right)$ as a function of the $\mathrm{B}$ content.

The Mott-Schottky plots of the BSSs shown in Figure 10a exhibit two potential sections showing linear increase, between -0.35 and $0 \mathrm{~V}_{\mathrm{SCE}}$ (Region I) and between 0 and $0.4 \mathrm{~V}_{\mathrm{SCE}}$ (Region II). Using the positive $\Delta C_{\text {total }}{ }^{-2} / \Delta V$ values in Regions I and II, the shallow and deep donor densities can be estimated, respectively.

The average point defect density values of the BSSs are presented in Figure 10b as a function of the $B$ content. Figure 10b clearly shows that the densities of both shallow and deep donors increase with the increase in the B content. The average shallow donor density of the B019 alloy was $3.49 \times 10^{20} \mathrm{~cm}^{-3}$ and that of the B176 alloy was $4.32 \times 10^{20} \mathrm{~cm}^{-3}$. In addition, the average deep donor density increased from $17.51 \times 10^{20} \mathrm{~cm}^{-3}$ for the B019 alloy to $24.27 \times 10^{20} \mathrm{~cm}^{-3}$ for the B176 alloy. The high point defect density in the passive film implies a large amount of charge carrier in the passive film which well explains the higher $\mathrm{i}_{\text {passive }}$ of the B176 alloy than that of the B019 alloy in the polarization curves, as 
shown in Figure 8 b. In addition, Figure $10 \mathrm{~b}$ also demonstrates that the alloy containing more $\mathrm{B}$ forms more defective and, hence, less protective passive film; thus, the results from Figure 10b are partly responsible for the degraded resistance to pitting corrosion of the B176 alloy shown in Figures 5 and 6 .

The noticeable point in Figure $10 \mathrm{~b}$ is the change in the $\mathrm{Cr}^{6+}$ concentration. The density of $\mathrm{Cr}^{6+}$ in the passive film significantly increased with the increase in B content in the BSSs, which corresponded to the XPS analysis result (Figure 9e). It is generally accepted that the passive film of stainless steel (FeCr-based alloys) containing higher $\mathrm{Cr}$ is more protective [28,36,37], resulting in the enhancement of the resistance against passive breakdown. However, in the case of BSSs, the passive film formed on the B176 alloy exhibited the lowest resistance to pitting corrosion although the film contained the highest $\mathrm{Cr}$ concentration. This discrepancy can be explained as follows: First, the overall resistance against pitting corrosion of the BSSs shown in Figures $5-7$ is primarily determined by the surface heterogeneity (i.e., $\mathrm{Cr}_{2} \mathrm{~B}$ ), which provides the pit initiation site, in comparison with the protective ability of the passive film. Second, the detrimental contribution of $\mathrm{Cr}_{2} \mathrm{~B}$ to the overall passivation is considered. As discussed in Section 3.1, the $\mathrm{Cr}$ content in the solid solution state in the austenite matrix decreased from 16.67 to $9.21 \mathrm{wt} \%$ as the $\mathrm{B}$ addition increased from 0.19 to $1.76 \mathrm{wt} \%$ because of the $\mathrm{Cr}_{2} \mathrm{~B}$ formation. Thus, the higher $\mathrm{Cr}$ concentration in the passive film on the BSS with higher $\mathrm{B}$ content is considered as evidence of the passivation of $\mathrm{Cr}_{2} \mathrm{~B}$. However, the electrical conductivity of the $\mathrm{Cr}_{2} \mathrm{~B}$ is lower than that of the austenite matrix [38], and the volume fraction of $\mathrm{Cr}_{2} \mathrm{~B}$ remarkably increases as the $B$ addition increases; thus, the formation of a stable and continuous passive film on the B-containing alloy is inhibited. As a result, a thin (Figure 9d) and defective passive film is formed on the alloy with high B content.

\section{Conclusions}

The resistance to pitting corrosion and passive behavior of type 304 stainless steels $\left(\mathrm{Fe}_{\text {balance }} 18 \mathrm{Cr} 12 \mathrm{Ni1} .5 \mathrm{Mn}\right.$-based alloys, in wt \%) containing $0.19-1.76 \mathrm{wt} \% \mathrm{~B}$, which were manufactured through conventional ingot metallurgy, were investigated. The pitting corrosion resistance was evaluated through potentiodynamic polarization and immersion tests in aqueous solutions with $\mathrm{Cl}^{-}$. The passive behavior was examined in a borate-phosphate-citric buffer solution at $\mathrm{pH} 8.5$ through potentiodynamic polarization tests. The physicochemical and electronic properties of the passive film were examined using XPS and Mott-Schottky analyses. On the basis of the tests, the following conclusions could be drawn.

1. The borated stainless steels were composed of austenitic matrix and $\mathrm{Cr}_{2} \mathrm{~B}$ phase. As the $\mathrm{B}$ content increased from 0.19 to $1.76 \mathrm{wt} \%$, the volume fraction of $\mathrm{Cr}_{2} \mathrm{~B}$ increased from 1.68 to $22.66 \mathrm{vol}$ $\%$, and the concentration of $\mathrm{Cr}$ in solid solution state in the austenitic matrix was lowered from 16.67 to $9.21 \mathrm{wt} \%$. In addition, the grain size of the austenite matrix decreased as the $\mathrm{Cr}_{2} \mathrm{~B}$ fraction increased.

2. In various $\mathrm{NaCl}$ solutions, lower pitting corrosion resistance was observed in the alloy with higher $\mathrm{B}$ content. The pits were initiated at the matrix adjacent to the $\mathrm{Cr}_{2} \mathrm{~B}$ and propagated into the matrix.

3. Regarding the passive behavior, the passive current density increased as the B content in the alloy increased. The passive films of the borated stainless steels formed in borate-phosphate-citric buffer solution ( $\mathrm{pH}$ 8.5) were ( $\mathrm{Fe}, \mathrm{Cr}$ )-oxides. With an increase in the $\mathrm{B}$ addition, the passive film thickness decreased from 2.5 to $1.8 \mathrm{~nm}$, and the $\mathrm{Cr}$ content in the passive film slightly increased. Furthermore, Mott-Schottky analysis confirmed that more defective passive film was formed on the alloy with higher B content.

4. The reduced resistance to pitting corrosion of the B-bearing type 304 stainless steel along with the increase in the $B$ content was due to the formation of a more defective and thinner passive film and a larger number of pit initiation sites in the matrix. 
Author Contributions: 1. H.-Y.H. (corresponding author): Electrochemical tests and comprehensive analysis; 2. J.H.J.: Phase prediction and microstructural analysis; 3. T.-H.L.: Microstructure and composition analyses through TEM and EPMA; 4. C.W.: Sample preparation for microstructural analysis and phase quantification; 5. C.-H.L.: Alloy design and fabrication, and controlling the fabrication process; 6. J.M.: Accurate analysis of the second phases through TEM and EPMA; 7. C.-G.L.: Sample preparation for polarization and immersion tests.

Acknowledgments: This study was financially supported by Fundamental Research Program (grant number PNK5850) of the Korea Institute of Materials Science (KIMS).

Conflicts of Interest: The authors declare no conflict of interest.

\section{References}

1. Machiels, A.; Lambert, R. Handbook of Neutron Absorber Materials for Spent Nuclear Fuel Transportation and Storage Applications, 2009 ed.; EPRI: Palo Alto, CA, USA, 2009; p. 2.

2. Brown, R.S. Corrosion Resistance of Borated Stainless Steels; Carpenter Powder Products: Wyomissing, PA, USA, 1991; p. 657.

3. Robino, C.V.; Cieslak, M.J. High-temperature metallurgy of advanced borated stainless steels. Metall. Mater. Trans. A 1995, 26, 1673-1685. [CrossRef]

4. He, J.Y.; Soliman, S.E.; Bratta, A.J.; Balliett, T.A. Fracture Mechanism of Borated Stainless Steel. Nucl. Technol. 2000, 130, 218-225. [CrossRef]

5. Fix, D.V.; Estill, J.C.; Wong, L.L.; Rebak, R.B. General and Localized Corrosion of Austenitic and Borated Stainless Steels in Simulated Concentrated Ground Waters. In Proceedings of the American Society of Mechanical Engineers Pressure Vessels and Piping Division (ASME-PVP) Conference, San Diego, CA, USA, 25-29 July 2004.

6. Moreno, D.A.; Molina, B.; Ranninger, C.; Montero, F.; Izquierdo, J. Microstructural Characterization and Pitting Corrosion Behavior of UNS S30466 Borated Stainless Steel. Corrosion 2004, 60, 573-583. [CrossRef]

7. Lister, T.E.; Mizia, R.E.; Erickson, A.W.; Matteson, B.S. General and Localized Corrosion of Borated Stainless Steels; INL/CON-07-135355; Idaho National Laboratory: Idaho Falls, ID, USA, 2008.

8. He, X.; Ahn, T.; Sippel, T. Corrosion of Borated Stainless Steel in Water and Humid Air; NRC-02-07-006; Nuclear Regulatory Commission: Rockville, MD, USA, 2011.

9. Shanmugarajan, B.; Chary, J.N.; Padmanabham, G.; Arivazhagan, B.; Shaju, K.A.; Bhaduri, A.K. Studies on autogenous laser welding of type 304B4 borated stainless steel. Opt. Laser Eng. 2013, 51, 1272-1277.

10. RajaKumar, G.; Ram, G.D.J.; Rao, S.R.K. Microstructure and Mechanical properties of Borated Stainless Steel (304B) GTA and SMA welds. La Metall. Ital. 2015, 5, 47-52.

11. Sivai Bharasi, N.; Pujar, M.G.; Nirmal, S.; Mallika, C.; Kamachi Mudali, U.; Angelo, P.C. Comparison of SCC Behavior of 304L Stainless Steels With and Without Boron Addition in Acidic Chloride Environment. J. Mater. Eng. Perform. 2016, 5, 2786-2798. [CrossRef]

12. American Society for Testing and Materials (ASTM) A 887-89. Standard Specification for Borated Stainless Steel Plate, Sheet, and Strip for Nuclear Application; ASTM: West Conshohocken, PA, USA, 2004.

13. Loria, E.A.; Isaacs, H.S. Type 304 stainless steel with $0.50 \%$ boron for storage of spent nuclear fuel. JOM 1980, 32, 10-17. [CrossRef]

14. Hoffman, J.P.; De Jesus, A.S.M. The distribution of boron in stainless steels as revealed by a nuclear technique. J. S. Afr. Inst. Min. Metall. 1989, 89, 81-87.

15. Levitin, V.V.; Syreishchikova, V.I. On the effect of boron on the nature of the carbide precipitation in austenitic steel on tempering. Fiz. Met. Metallovdenie 1959, 7, 308-310.

16. Farrell, J.W.; Rosenthal, P.C. How boron affects corrosion of type 304 stainless steel. Met. Prog. 1960, 77, 101-103.

17. Robinson, F.P.A.; Scurr, W.G. The effect of boron on the corrosion resistance of austenitic stainless steels. Corrosion 1977, 33, 408-417. [CrossRef]

18. Dergach, T.A.; Sukhomlin, G.D. Effect of boron on the structure and intercrystalline-corrosion resistance of austenitic stainless steel. Prot. Met. 1990, 25, 390-394.

19. Goldschmidt, H.J. Effect of Boron Additions to Austenitic Stainless Steels. J. Iron Steel Inst. 1971, $209,900-911$.

20. Upadhyay, N.; Pujar, M.G.; Das, C.R.; Mallika, C.; Kamachi Mudali, U. Pitting Corrosion Studies on Solution-Annealed Borated Type 304L Stainless Steel Using Electrochemical Noise Technique. Corrosion 2014, 70, 781-795. [CrossRef] 
21. Sundman, B.; Jansson, B.; Andersson, J.O. The Thermo-Calc Databank System. Calphad 1985, 9, $153-190$. [CrossRef]

22. Novak, E.; Schmit, J. White-light optical profiler with integrated primary standard. In Proceedings of the XVII IMEKO World Congress Metrology in the 3rd Millennium, Dubrovnik, Croatia, 22-27 June 2003; pp. 183-186.

23. Ha, H.-Y.; Kwon, H.-S. Effects of pH Levels on the Surface Charge and Pitting Corrosion Resistance of Fe. J. Electrochem. Soc. 2012, 159, C416-C421. [CrossRef]

24. Jiang, S.Z.; Bao, Y.Z. A study of the brittleness and its improvement of high boron Cr-Ni stainless steels. Inst. Tech. Bull. 1993, 3, 194-198.

25. Piao, T.; Park, S.-M. Spectroelectrochemical Studies of Passivation and Transpassive Breakdown Reactions of Stainless Steel. J. Electrochem. Soc. 1997, 144, 3371-3377. [CrossRef]

26. Cho, E.A.; Kwon, H.S.; Macdonald, D.D. Photoelectrochemical analysis on the passive film formed on Fe-20Cr in pH 8.5 buffer solution. Electrochim. Acta 2002, 47, 1661-1668. [CrossRef]

27. Kuczynska-Wydorska, M.; Flis-Kabulska, I.; Flis, J. Corrosion of low-temperature nitrided molybdenum-bearing stainless steels. Corros. Sci. 2011, 53, 1762-1769. [CrossRef]

28. Ha, H.-Y.; Lee, T.-H.; Kim, S.-J. Role of nitrogen in the active-passive transition behavior of binary Fe-Cr alloy system. Electrochim. Acta 2012, 80, 432-439. [CrossRef]

29. Obayi, C.S.; Tolouei, R.; Mostavan, A.; Paternoster, C.; Turgeon, S.; Okorie, B.A.; Obikwelu, D.O.; Mantovani, D. Effect of grain sizes on mechanical properties and biodegradation behavior of pure iron for cardiovascular stent application. Biomatter 2016, 6, e959874. [CrossRef] [PubMed]

30. Sabooni, S.; Rashtchi, H.; Eslami, A.; Karimzadeh, F.; Enayati, M.H.; Raeissi, K.; Ngan, A.H.W.; Imani, R.F. Dependence of corrosion properties of AISI 304L stainless steel on the austenite grain size. Int. J. Mater. Res. 2017, 108, 552-559. [CrossRef]

31. Lee, C.-G.; Ha, H.-Y.; Lee, T.-H.; Cho, K.-M. Effects of Nb on Pitting Corrosion Resistance of Ni-Free FeCrMnCN-Based Stainless Steels. J. Electrochem. Soc. 2017, 164, C591-C597. [CrossRef]

32. Di Schino, A.; Kenny, J.M. Effects of the grain size on the corrosion behavior of refined AISI 304 austenitic stainless steels. J. Mater. Sci. Lett. 2002, 21, 1631-1634. [CrossRef]

33. Hubschmid, C.; Landolt, D.; Mathieu, H.J. XPS and AES analysis of passive films on Fe-25Cr-X (X= Mo, V, Si and Nb) model alloys. Fresenius J. Anal. Chem. 1995, 353, 234-239. [CrossRef]

34. Yang, M.Z.; Luo, J.L.; Yang, Q.; Qiao, L.J.; Qin, Z.Q.; Norton, P.R. Effects of Hydrogen on Semiconductivity of Passive Films and Corrosion Behavior of 310 Stainless Steel. J. Electrochem. Soc. 1999, 146, 2107-2112. [CrossRef]

35. Paola, A.D. Semiconducting properties of passive films on stainless steels. Electrochim. Acta 1989, 34, $203-210$. [CrossRef]

36. Ha, H.-Y.; Jang, M.-H.; Lee, T.-H. Influences of Mn in solid solution on the pitting corrosion behaviour of Fe-23 wt \%Cr-based alloys. Electrochim. Acta 2016, 19, 864-875. [CrossRef]

37. Ha, H.-Y.; Lee, T.-H.; Oh, C.-S.; Kim, S.-J. Effects of combined addition of carbon and nitrogen on pitting corrosion behavior of Fe-18Cr-10Mn alloys. Scr. Mater. 2009, 61, 121-124. [CrossRef]

38. Kislyi, P.S.; L'vov, S.N.; Nemchenko, V.F.; Samsonov, G.V. Physical properties of the boride phases of chromium. Sov. Powder Metall. Met. Ceram. 1962, 1, 441-443. [CrossRef]

(c) 2018 by the authors. Licensee MDPI, Basel, Switzerland. This article is an open access article distributed under the terms and conditions of the Creative Commons Attribution (CC BY) license (http://creativecommons.org/licenses/by/4.0/). 